\title{
Invasive methods of hepatocellular carcinoma treatment
}

\author{
Gulziya Ismailova $^{1}$, Eugene Yenin $^{2}$, Shokan Kaniev $^{3}$, Talgat Tajibaev $^{1}$, Altynshash Baichalova $^{4}$, Almat Chormanov $^{3}$, \\ Bolatbek Baimakhanov 5 .
}

${ }^{1}$ Departments of Science Management, JSC “National scientific center of surgery”, Almaty, Kazakhstan ${ }^{2}$ Department of Pathology, JSC "National scientific center of surgery", Almaty, Kazakhstan

${ }^{3}$ Department of Hepatology, JSC "National scientific center of surgery”, Almaty, Kazakhstan

${ }^{4}$ Department of Clinical laboratory diagnostics,

JSC "National scientific center of surgery", Almaty,

Kazakhstan

${ }^{5}$ Department of Surgery, JSC "National scientific center of surgery”, Almaty, Kazakhstan

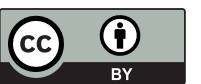

This work is licensed under a

Creative Commons Attribution 4.0

International License

Received: 06-08-2017

Accepted: 03-10-2017

J Clin Med Kaz 2017;4(46):11-13

Corresponding Author: Gulziya Ismailova, MD,

$\mathrm{PhD}$, Science Department, JSC "National scientific

center of surgery", 050004, Kazakhstan.

E-mail: dr.ismailova@mail.ru.

Phone numbers: +7 7018228188 ;

Fax numbers: + 7 (727) 2799505 ;

\section{Abstract}

Hepatocellular carcinoma is the fifth most common malignant neoplasm and is the third common cause of death from cancer. Despite significant advances in the development of surgical methods and new anticancer medicines, the overall survival rates HCC remain low due to high incidence of relapse or intrahepatic metastases after treatment. The mini-review is devoted to analysis of invasive treatment methods hepatocellular carcinoma for determining the tactics of surgical treatment.

Key words: hepatocellular carcinoma, liver resection, transarterial chemoembolization

\section{ГЕПАТОЦЕЛЛЮЛЯРДЫ КАРЦИНОМАНЫ ЕМДЕУ ИНВАЗИВТІ ТӘСІЛДЕР}

Исмаилова Гулзия ${ }^{1}$, Енин Евгений ${ }^{2}$, Қаниев Шоқан ${ }^{3}$, Тәджибаев Талғат ${ }^{1}$, Байшалова Алтыншаш ${ }^{4}$ Шорманов Алмат ${ }^{3}$, Баймаханов Болатбек ${ }^{5}$

ҒҒылым бөлімі, А.Н.Сызғанов атындағы Ұлттық ғылыми хирургия орталығы. Алматы, Қазақстан.

ППатоморфология бөлімі, А.Н.Сызғанов атындағы Ұлттық ғылыми хирургия орталығы. Алматы, Қазақстан.

${ }^{3}$ Гепатология бөлімі, А.Н.Сызғанов атындағы Ұлттық ғылыми хирургия орталығы. Алматы, Қазақстан.

${ }^{4}$ Клиникалық зертханалық диагностика бөлімі, А.Н.Сызғанов атындағы Ұлттық ғылыми хирургия орталығы. Алматы, Қазақстан.

${ }^{5}$ Хирургия бөлімі, А.Н.Сызғанов атындағы Ұлттық ғылыми хирургия орталығы. Алматы, Қазақстан.

Гепатоцеллюлярды карциномасы бесінші ең көп тараған қатерлі ісік болып табылады және үшінші онкологиялық өлім-жітімнің жалпы себебі болып табылады. хирургиялық емдеу әдістерін және жаңа обырға қарсы дәрі-дәрмектерді дамытуға айтарлықтай дәмыныуна қарамастан, ГЦК бар науқастарды жалпы өмір сүру салдарынан қайталануына немесе өңдеуден кейін бауырішілік метастазов жиілігі жоғары төмен болып қалуда. Мини-шолу хирургиялық өңдеуді анықтау үшін Гепатоцеллюлярды карциномасы жолдары инвазивті емдеу талдайды.

Түйінді сөздер: Гепатоцеллюлярды карциномасы, бауыр резекциясы, тамырарқалы химиоэмболизациасы 
ИНВАЗИВНЫЕ МЕТОДЫ ЛЕЧЕНИЯ ГЕПАТОЦЕЛЛЮЛЯРНОЙ КАРЦИНОМЫ

Исмаилова Гулзия ${ }^{1}$, Енин Евгений ${ }^{2}$, Қаниев Шоқан ${ }^{3}$, Тәджибаев Талғат ${ }^{1}$, Байшалова Алтыншаш ${ }^{4}$, Шорманов Алмат ${ }^{3}$, Баймаханов Болатбек ${ }^{5}$

'Отдел науки АО «Национальный научный центр хирургии имени А.Н. Сызганова», Алматы, Казахстан

${ }^{2}$ Отдел патоморфологии, «Национальный научный центр хирургии имени А.Н. Сызганова», Алматы, Казахстан

${ }^{3}$ Отдел гепатологии, «Национальный научный центр хирургии имени А.Н. Сызганова», Алматы, Казахстан

${ }^{4}$ Отдел клинической лабораторной диагностики, «Национальный научный центр хирургии имени А.Н. Сызганова», Алматы, Казахстан

${ }^{5}$ Отдел хирургии, «Национальный научный центр хирургии имени А.Н. Сызганова», Алматы, Казахстан

\section{PEЗЮME}

Гепатоцеллюлярная карцинома является пятым наиболее распространенным злокачественным новообразованием и является третьей общей причиной смертности от рака. Несмотря на значительные успехи в развитии хирургических методов лечения и новых противоопухолевых препаратов, показатели общей выживаемости больных ГЦК остаются низкими из-за высокой частоты рецидивов или внутрипеченочных метастазов после лечения. Мини-обзор посвящен анализу способов инвазивного лечения гепатоцеллюлярной карциномы для определения тактики хирургического лечения.

Ключевые слова: Гепатоцеллюлярная карцинома, резекция печени, трансартериальная химиоэмболизация

\section{Введение}

Согласно данным GLOBOCAN 2012, в Казахстане, гепатоцеллюлярная карцинома (ГЦК) является одной из наиболее распространенных форм рака - 7.93 на 100000 населения, из них у мужчин 12.18, а у женщин заболеваемость составила 5.25. Смертность от ГЦК 7.57 на 100000 населения, из них у мужчин 12.02, а у женщин 4,87 [1]. В целом в мире, ГЦК является причиной 500000 смертельных случаев в год. Распространенность ГЦК в Европейском союзе составляет 8.29 на100 000, а во всем Азиатском регионе вместе со странами Африки, где самая высокая заболеваемость инфекционным гепатитом, заболеваемость ГЦК составляет 120 случаев на 100000 [2].

Высокая частота ГЦКу мужчин связана с хроническими заболеваниями печени, вследствие перенесенного гепатит B (HBV), гепатит C (HCV) и алкогольного цирроза печени. Сочетание факторов риска, к примеру хронической инфекции вирусным гепатитом В (HBV) и цирроза печени увеличивает риск развития ГЦК в 100-крат. Приблизительно 5-30\% больных перенесших HCV, впоследствии страдают хроническими заболеваниями печени, из них у $30 \%$ болезнь прогрессируют в цирроз печени и ГЦК $[3,4]$.

Известно, что злоупотребление алкоголем в сочетании с хронической инфекции HCV удваивает риск ГЦК по сравнению с одной только инфекцией $\mathrm{HCV}$. Наибольшая заболеваемость приходится на возраст 50-60 лет. В странах Африки и Азии, возраст заболевших раком печени существенно моложе и составляет 40 лет в африканских и 50 лет в азиатских странах $[4,5]$.

\section{Группы риска}

Пациенты группы высокого риска развития ГЦК (носители HBV с циррозом печени, пациенты без цирроза с высокой концентрацией $\mathrm{HBV}$, пациенты c HCV-связанным или алкогольным циррозом печени) должны быть включены в специальные программы наблюдения для раннего обнаружения ГЦК, поддающегося хирургическому лечению. Наблюдение необходимо выполнять с использованием УЗИ каждые 6-12 месяцев, в сочетании с мониторингом уровня АФП [5]. Однако, нет подтверждающих данных, что ранняя диагностика заболевания приведет к улучшению выживаемости у пациентов с циррозом печени Child-Pugh В и С [4].

\section{Инвазивные метод лечения}

Резекция печени R0 (резекция с хирургическими краями без опухоли) является выбором первой-линии хирургического лечения у пациентов с локализованными и операбельными опухолями не страдающих циррозом печени или Child-Pugh A пациентов с циррозом печени, что по некоторым литературным данным обеспечивает 3-х летнюю выживаемость у 54\% пациентов с ГЦК не страдающих циррозом печени.

На сегодня, трансплантация печени при ГЦК является методом хирургического лечения с долгосрочным эффектом у пациентов с ГЦК с циррозом печени потому, что предлагает возможность лечения, как опухоли, так и основного заболевания печени. Хотя, вопрос трансплантации печени, в лечении ГЦК, долгое время был спорным [6]. Трансплантация печени рекомендуется пациентам с одиночным узлом размером не более 5 см или тремя узлами размерами менее 3 см, которые не подходят для резекции. Данный Миланский критерий гарантируют 5-летнюю выживаемость, сводную от болезни и общую выживаемость более $65 \%$ [7]. В случае длительного времени ожидания реципиентом донора (более 6 месяцев), рекомендуется резекция, местная абляция или трансартериальная химиоэмболизация, чтобы свести к минимуму риск прогрессирования опухоли и предложить «мост» для трансплантации [8]

Трансартериальная химиоэмболизация (ТАХЭ) является общепринятым стандартом лечения ГЦК с циррозом печени или паллиативным методом лечения, как соединяющий «мост» до трансплантации печени. Принцип ТАХЭ заключается во внутриартериальной инъекцией комбинации цитотоксических препаратов (доксирубицин или цисплатин и/или митомицин) в печеночную артерию, сопровождаемую инъекцией Липиодола Ультра-флюида, a также Gelfoam для окклюзии сосуда [9,10]. Согласно местному распространению болезни и печеночному функциональному запасу, ТАХЭ может быть выполнен как 'полностью' отобранным или супер-отборным, с выполнением через микрокатетер. Противопоказаниями к ТАХЭ являются цирроз печени Child-Pugh B $\geq 8$, Child-Pugh $\mathrm{C}$, наличие многофокального билобарной диссеминации опухоли, внепеченочные метастазы, тромбоз портальной вены или артерио-портальной фистула, клиренса креатинина $<30$ мл/мин [11]. ТАСЕ рекомендуется пациентам с ГЦК BCLC стадии B, многоузловой бессимптомный ГЦК без сосудистой инвазии и внепеченочных метастазов [10]

Радиочастотная абляция (РЧА) широко применяется как паллиативный метод лечения ГЦК, или как соединяющая «мост» до пересадки печени. Выполняется под контролем ультрасонографии или КТ, а также во время лапароскопических и открытых операций. У метода имеются ограничения по сравнению с ТАХЭ: до трех узлов 
больше в центре или максимальный диаметр узла до 5 см. Положительным эффектом считается, когда достигается $100 \%$ некроз опухоли, который очень сложно достигнуть $[12,13]$.

Радиоэмболизация микросферами Йттрия-90 (Y90) является не хирургической процедурой, одобренной FDA для лечения неоперабельного ГЦК. Радиоэмболизация микросферами Йттрия-90 является таргетной, внутренней радиационной терапией непосредственно опухоли. Этот метод лечения применяют в сочетании с частичный гепатоэктомией и пересадкой печени или как основной метод лечения ГЦКдля пациентов с диффузным внутрипеченочным распространением опухоли [14]. Техника выполнения процедуры, заключается во введение катетера в печеночной артерии, через который микросферы содержащие радиоактивный Ү90, выпускаются в печеночный кровоток. Эти микросферы размещаются в меньших кровеносных сосудах, которые питают опухоль. Оказывается двойной лечебный эффект, помимо эмболизации микросферами, которая предотвращает кровоток в опухоли, дополнительно радиоактивные микросферы испускают радиацию, которая помогаетразрушить раковыеклетки. Таргетная природаэтого подхода, позволяет донести до раковых клеток достаточно высокой дозы облучения, чем обычная радиотерапия. Доза радиоактивности Ү90 снижается в течение 2-х недель, за это время радиоактивность полностью исчезает. Число и размер опухолей не определяют эффективность лечения. Лечение микросферами Y90 имеет преимущество своей способностью лечить все внутрипеченочные повреждения ГЦК, включая необнаруженные опухоли. Радиоэмболизация микросферами Йттрия-90, также может быть альтернативой ТАХЭ [15].

Чрескожная инъекция этанола, криотерапия, микроволновая терапия коагуляции - альтернативные методы РЧА, которые не нашили широкого применение как РЧА. Хотя, чрескожная инъекция этанола рекомендуется для применения у пациентов с $3-4$ небольшими опухолевыми узлами, с максимальным размером менее 5 см. Эффективность чрескожной инъекция этанола явно ниже по сравнению с РЧА при опухолях более 5 см [16].

\section{Выводы}

Инвазивное лечение ГЦК порой является единственным способом лечения больного ГЦК, что указывает на необходимость более четких критериев определения тактики лечения.

\section{Литература}

1. GLOBOCAN 2012. Estimated cancer incidence, mortality and prevalence worldwide in 2012. Simple maps. http://globocan.iarc. fr/Default.aspx.

2. Parkin DM, Bray F, Ferlay J et al. Global cancer statistics, 2002. CA Cancer J Clin. 2005;55:74-108.

3. Jin-Kyoung Oh, Hai-Rim Shin, Min Kyung Lim et al. Multiplicative synergistic risk of hepatocellular carcinoma development among hepatitis B and C co-infected subjects in HBV endemic area: a community-based cohort study. BMC Cancer. $2012 ; 12: 452$.

4. Chen CJ, Yang HI, Su J et al.; REVEAL-HBV Study Group. Risk of hepatocellular carcinoma across a biological gradient of serum hepatitis B virus DNA level. JAMA. 2006;295:65-73.

5. Masao Omata, Ann-Lii Cheng, Norihiro Kokudo et al. Asia-Pacific clinical practice guidelines on the management of hepatocellular carcinoma: a 2017 update. Hepatol Int. 2017;11:317-370.

6. Michael A. Choti. Transplantation Versus Resection for Hepatocellular Carcinoma in the Mild Cirrhotic: Framing the Debate. $J$ Gastrointest Surg. 2009;13:1021-22.

7. Sotiropoulos GC, Molmenti EP, Lang H. Liver transplantation for hepatocellular carcinoma in the MELD era: leading roles of MELD score, AFP level, and recipient age as predictors of survival.Dig Dis Sci. 2009;54:917.

8. 8. Reena JS, Nathan PG, Jorge AM. et al. Donor Factors Similarly Impact Survival Outcome After Liver Transplantation in Hepatocellular Carcinoma and Non-hepatocellular Carcinoma Patients. Dig Dis Sci. 2014; 59:214-19.

9. Mario S, Gianluca SB, Luca F et al Trans-arterial chemo-embolization (TACE), with either lipiodol (traditional TACE) or drugeluting microspheres (precision TACE, pTACE) in the treatment of hepatocellular carcinoma: efficacy and safety results from a large mono-institutional analysis. J Exp Clin Cancer Res. 2010;29:164-172.

10. Mituo S., Hideo U., Yasuaki Arai et al. Transcatheter Arterial Chemoembolization (TACE) with Lipiodol to Treat Hepatocellular Carcinoma: Survey Results from the TACE Study Group of Japan. Cardiovasc Intervent Radiol. 2008;31:756-61.

11. Jiazhi Li, Zhiyong Dong, Xinjing Zhang et al. Transcatheter arterial chemoembolization in combination with stereotactic body radiation therapy in primary liver carcinoma: a systematic review and meta-analysis. Int J Clin Exp Med. 2017;10(2):1816-27.

12. Andrea V, Paolo M, Andrea D et al Radiofrequency thermal ablation (RFA) after transarterial chemoembolization (TACE) as a combined therapy for unresectable non-early hepatocellular carcinoma (HCC). Eur Radiol. 2006;16:661-9.

13. R Benevento, A Santoriello, G Perna et al Efficacy of percutaneous radiofrequency ablation (RFA) for hepatocellular carcinoma in elderly patients. BMC Geriatrics. 2011;11 Suppl 1:A45.

14. Xing M, Lahti S, Kokabi N, et al. 90Y Radioembolization Lung Shunt Fraction in Primary and Metastatic Liver Cancer as a Biomarker for Survival. Clin Nucl Med. 2016;41(1):21-7.

15. Ting-Shuo H, Yu-Chiau Sh., Robin T. et al Diagnostic performance of alpha-fetoprotein, lens culinaris agglutinin-reactive alphafetoprotein, des-gamma carboxyprothrombin, and glypican-3 for the detection of hepatocellular carcinoma: a systematic review and meta-analysis protocol. Systematic Reviews. 2013;2:37-45.

16. Lewandowski RJ, Kulik LM, Riaz A, et al. Comparative analysis of transarterial downstaging for hepatocellular carcinoma: chemoembolization versus radioembolization. Am J Transplant. 2009;9:1920-8.

How to cite this article: Gulziya Ismailova, Eugene Yenin, Shokan Kaniev, Talgat Tajibaev, Altynshash Baichalova, Almat Chormanov, Bolatbek Baimakhanov. Invasive methods of hepatocellular carcinoma treatment [in Russian]. J Clin Med Kaz 2017;4(46):11-13 